\title{
A case of extragastrointestinal stromal tumor complicated by severe hypoglycemia: a unique presentation of a rare tumor
}

\author{
Zeb Saeed ${ }^{1}$, Solaema Taleb ${ }^{1}$ and Carmella Evans-Molina ${ }^{1,2,3,4,5^{*}}$ [D
}

\begin{abstract}
Background: Non-Islet Cell Tumor Hypoglycemia (NICTH) is a rare paraneoplastic cause of hypoglycemia arising from excess tumor production of insulin-like growth factor. The objective of this report is to describe an unusual case of Extragastrointestinal Stromal Tumor (EGIST) associated NICTH.

Case presentation: A 64 year-old African female was brought to the emergency room with a 1-month history of recurrent syncope, weight loss, and abdominal bloating. Serum blood glucose was discovered to $39 \mathrm{mg} / \mathrm{dL}$, when insulin, proinsulin, and C-peptide were suppressed. Computed tomography scan revealed a diffuse extraintestinal metastatic disease process, and a biopsy confirmed the diagnosis of an Extragastrointestinal Stromal Tumor (EGIST). IGF-I and II levels were $27 \mathrm{ng} / \mathrm{ml}$ and $262 \mathrm{ng} / \mathrm{ml}$ respectively, and the ratio of IGF-II to IGF-I was calculated as 9.7:1, suggestive of IGF-II-mediated NICTH. Acutely, the patient's hypoglycemia resolved with dextrose and glucagon infusion. Long-term euglycemia was achieved with prednisone and imatinib therapy.

Conclusions: NICTH should be considered when hypoglycemia occurs in the setting of low serum insulin levels. Whereas definitive treatment of EGIST involves surgical resection, immunotherapy with tyrosine kinase inhibitors and corticosteroids have been shown to alleviate hypoglycemia in cases where surgery is delayed or not feasible.
\end{abstract}

Keywords: Tumor induced hypoglycemia, Extragastrointestinal stromal tumor (GIST), Non-islet cell tumor hypoglycemia

\section{Background}

Tumor induced hypoglycemia can be divided into two broad categories. The first involves insulin hypersecretion from pancreatic islet cell insulinomas. The second, known as Non-Islet Cell Tumor Hypoglycemia (NICTH), is from paraneoplastic production of insulin-like growth factor from a tumor, leading to unrestrained glucose uptake at peripheral tissues $[1,2]$. The first description of NICTH dates back to 1929 and involved a patient with metastatic hepatocellular carcinoma. Post-mortem examination of the pancreas was normal. Furthermore, analysis of the

\footnotetext{
* Correspondence: cevansmo@iu.edu

'Departments of Medicine, Indiana University School of Medicine, Indianapolis, USA

${ }^{2}$ Celllular and Integrative Physiology, Indiana University School of Medicine, Indianapolis, USA

Full list of author information is available at the end of the article
}

tumor failed to reveal the presence of insulin, thus leading to the conclusion that the hypoglycemia was non-insulin mediated [3]. Since this original description, a variety of tumors have been shown to exhibit NICTH. These primarily include tumors of mesenchymal and epithelial origin with hepatocellular carcinomas being among the most frequently implicated.

Gastrointestinal Stromal Tumor (GIST) is the most common mesenchymal tumor arising within the gastrointestinal (GI) tract. These tumors express the phenotype of the Interstitial Cells of Cajal or related stem cell-like precursors and are associated with somatic mutations of the tyrosine kinase receptors c-kit (CD117) and platelet-derived growth factor- $\alpha$ (PDGFR- $\alpha$ ) [4-6]. Over the last decade, a handful of case reports have described an association between GIST and NICTH [5]. In extremely rare cases, GIST can arise 
primarily outside the GI tract, where it is termed Extragastrointestinal Stromal Tumor (EGIST) [6, 7]. Representing less than $10 \%$ of all stromal tumors, EGISTs share the same histological features, immunophenotype, and biological behavior as GISTs. Most EGISTs originate in the lesser or greater omentum, the mesentery, or less commonly in the retroperitoneum, with very few cases reported of tumors arising from the abdominal wall itself $[6,8]$. While some sources suggest that EGISTs represent peritoneal metastases of undiagnosed GISTs or GISTs that may have detached from the intestinal wall during extensive extramural growth, others consider them to be primary tumors arising from multipotent mesenchymal stems cells of the extraintestinal tissue $[6,8,9]$. Surgery remains a mainstay for localized GIST/EGIST. However, immunotherapy with tyrosine kinase inhibitors (TKI), especially imatinib, has emerged as a promising neoadjuvant or alternative therapy.

Here, we describe the case of a patient presenting with a rare abdominopelvic EGIST tumor and recurrent episodes of severe symptomatic hypoglycemia. To the best of our knowledge, this is the first reported case linking EGIST and NICTH.

\section{Case Presentation}

A 64 year-old African female was brought to the emergency room in January 2016 with a chief complaint of recurrent syncope. Her serum blood glucose on arrival was $39 \mathrm{mg} /$ dL. A detailed review of systems was notable for nonspecific abdominal bloating and distension and a $50 \mathrm{lb}$ weight loss over the preceding year. Vital signs on presentation were within normal limits; physical exam revealed a firm palpable right lower quadrant mass. Her past medical history revealed a history of pelvic EGIST that had been diagnosed in March 2010 at an outside facility. A computed tomography (CT) scan at that time demonstrated a large pelvic mass involving the right ovary, the mesovarian, and the mesometrium. Pathological analysis of the tumor revealed diffuse staining for $\mathrm{C}$-Kit, CD-34, and the smooth muscle marker caldesmon, while stains for pancytokeratin, S-100, Human Melanoma Black (HMB-45), Melan-A, actin, myogenin and desmin were all negative. The mitotic index was noted to be high at 28/50 high power fields, and tumor necrosis was noted. Following a debulking procedure, all intestinal specimens were found to tumor-free. Hence, the diagnosis of a primary EGIST was made. Postoperatively, she was started on immunotherapy with the TKI, imatinib. Since that time, the patient missed most of her follow-up appointments. During the current admission, she reported discontinuation of imatinib several months ago. She further noted that hypoglycemia had indeed been the initial manifestation of her EGIST in 2010, but this symptom had resolved post-operatively.

During the current admission, initial inpatient evaluation revealed a suppressed insulin $(<1 \mathrm{uIU} / \mathrm{mL})$, pro- insulin $(<1.4 \mathrm{pmol} / \mathrm{L}), \quad$-peptide $(0.4 \mathrm{ng} / \mathrm{mL})$ and $\beta$ hydroxy butyrate $(0.4 \mathrm{mg} / \mathrm{dL})$, when the serum blood glucose was $26 \mathrm{mg} / \mathrm{dL}$. A urine sulfonylurea screen was negative, and adrenal insufficiency was ruled out following documentation of a normal cortisol response to cosyntropin stimulation. A repeat CT scan revealed evidence of a diffuse metastatic disease with innumerable soft tissue peritoneal nodules of various sizes scattered throughout the abdomen (Fig. 1a). The largest mass was seen in the right lower quadrant and was $>7 \mathrm{~cm}$ in the largest dimension (Fig. 1b). Given biochemical and imaging findings, consideration for EGIST-associated NICTH was made. IGF-I and II levels were assayed and found to be $27 \mathrm{ng} / \mathrm{ml}$ (reference range: $75-263 \mathrm{ng} / \mathrm{mL}$ ) and $262 \mathrm{ng} / \mathrm{ml}$ (reference range: $47-350 \mathrm{ng} / \mathrm{mL}$ ), respectively. The ratio of IGF-II to IGF-I was calculated as 9.7:1.

Fine needle aspiration and core biopsy of the right lower quadrant mass were performed. H\&E staining revealed the typical spindle shaped morphology (Fig. 1c). Immunostaining for CD117 (Fig. 1d) and Discovered on GIST-1 (DOG-1) (Fig. 1e) were diffusely positive. Muscle specific actin (HHF-35), a mesenchymal marker present in $47 \%$ of GIST biopsies, was positive, while immunostaining for carcinoma markers were negative (not shown). Hence, a diagnosis of recurrent metastatic EGIST was made. Tumor sections were next stained with an antibody that recognized both big IGF-II and mature IGF-II (Abcam, Cambridge MA). Consistent with the patient's presentation with severe hypoglycemia, the tumor stained positive for big IGF-II/IGF-II (Fig. 1f).

\section{Discussion}

The true incidence of NICTH is unclear, but has been estimated to be extremely rare at approximately one per one million person years [10]. Hypoglycemia is thought to arise from excessive tumor production of IGF-II or its precursor high molecular weight "big" IGF-II. Hence the term "IGFII-oma" is often used to describe these tumors [1]. Both IGF-I and IGF-II are structurally related to insulin and act at peripheral insulin receptors to mimic insulin action, leading to increased glucose uptake, suppression of lipolysis, and inhibition of glycogenolysis, gluconeogenesis, and ketogenesis in the liver [11].

Under normal conditions, the liver produces IGF-II, in a growth hormone-independent manner, and IGF-II forms a biologically inactive ternary complex with IGF binding proteins (IGFBP), the most common of which are IGFBP3 and acid labile subunit (ALS) [12, 13]. Tumor-produced IGF-II has an equal affinity for IGFBPs compared to IGFI and II. However, instead of forming an inactive ternary complex, IGF-II forms smaller binary complexes with IGFBP. In NICTH, there is an increase in the quantity of unbound and active IGF-II as well as increased formation of these active binary complexes, which exhibit increased 

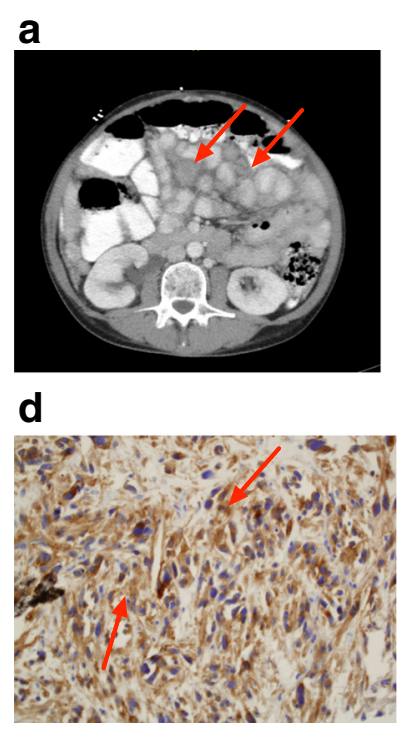

CD117 (c-kit) b

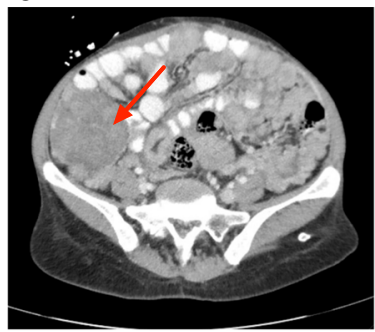

e

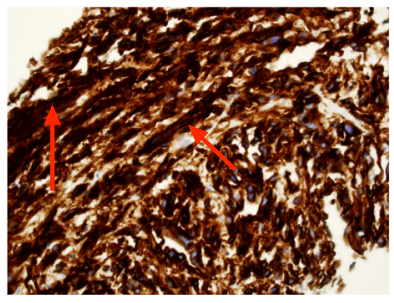

DOG-1

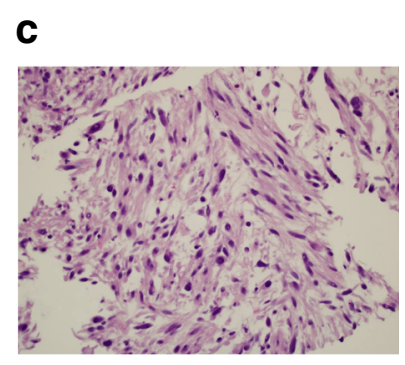

H\&E

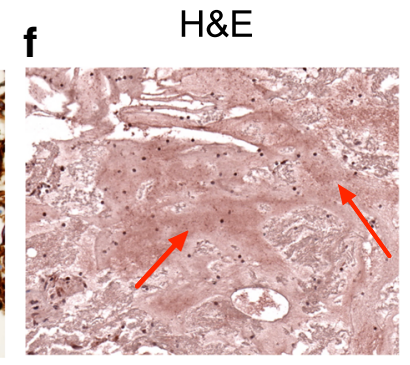

IGF-II

Fig. 1 Imaging and Pathologic Analysis of the Tumor. a-b Abdominal CT scan revealed diffuse intraabdominal metastatic disease. c Hematoxylin and eosin (H\&E) staining of the tumor revealed a spindle cell morphology (40X). Tumor immunostaining revealed the presence of $\mathbf{d}$ CD117 (40X); e DOG-1 (40X); and f IGF-II (20X)

vasculature permeability and significantly increased bioavailability. As a side mechanism, increased IGF-II in turn further suppresses hepatic IGFBP production, thus propagating further insulin like activity and creating a vicious cycle of severe and symptomatic hypoglycemia [12].

NICTH is typically a diagnosis of exclusion, but should be suspected when hypoglycemia without hyperinsulinemia is present. Biochemically, insulin, proinsulin, Cpeptide, growth hormone and $\beta$-hydroxybutyrate levels are low at the time of hypoglycemia, as was observed in this patient. In contrast, IGF-II or IGF-II precursor levels are often elevated. Typically an IGF-II:IGF-I ratio of 10:1 is considered pathognomonic, while a normal ratio is around 3:1 [1, 12]. In our patient, the levels were 9.7:1, which were quite high, though perhaps not diagnostic.

The range of tumors associated with NICTH is broad. In recent years, a handful of case reports and case series have described GIST-associated NICTH [4, 9, 11]. GIST tumors arise from the gut wall. In rare instances, they arise outside the GI tract in the omentum, mesentery, and retroperitoneum and are referred to as EGISTs. EGISTs share the same histological and immunotypic features and biological behavior as GISTs [4, 14]. The diagnosis of GIST/EGIST tumors relies on CD117 (cKIT) positivity on immunohistochemical staining, which remains a highly sensitive and specific marker.

Discovered on GIST-1 (DOG1) protein is another recently discovered tumor marker that has particularly utility in identifying tumors harboring mutations in plateletderived growth factor- $\alpha$ (PDGFR- $\alpha$ ) [15]. Whereas staining for both CD117 and DOG1 were observed in this patient's tumor, formal mutation analysis was not performed. Surgery remains the mainstay for localized GIST/ EGIST. However, immunotherapy with tyrosine kinase inhibitors (TKI), especially imatinib, has emerged as a promising neoadjuvant or alternative therapy. TKIs are especially useful in surgically unresectable or malignant tumors, and the advent of TKIs has increased median survival in such cases by nearly $50 \%[16,17]$.

Besides resection and therapy aimed at shrinking the underlying tumor, management of NICTH is typically independent of its location. A variety of approaches have been described in literature, including steroids, octreotide and human recombinant growth hormone (hGH) $[18,19]$. Notably, here we describe the use of continuous glucagon infusion as an effective treatment in the acute setting, especially when intravenous dextrose is ineffective alone. Among long-term interventions, glucocorticoids have demonstrated the most efficacy in terms of reversing the biochemical abnormalities associated with tumor production of IGF-II $[18,20]$. The proposed mechanism of glucocorticoids is thought to be suppression of IGF-II production by the tumor and/or its increased sequestration. Indeed published studies have demonstrated a significant fall in circulating big IGF-II, accompanied by an increase in serum ALS in response to prolonged glucocorticoid use. Interestingly, these changes were found to be reversible with glucocorticoid withdrawal. Furthermore, the required dose of steroid appears to be somewhat individualized and based on both tumor debulking strategies and the co-administration of other agents $[18,20]$. Table 1 summarizes available published studies in which steroids were used either solely or 
Table 1 Use of steroids in the treatment of inoperable NICTH

\begin{tabular}{|c|c|c|c|c|}
\hline Study & $\begin{array}{l}\text { Number of } \\
\text { patients }\end{array}$ & Glucocorticoid used (and dosages) $^{a}$ & $\begin{array}{l}\text { Duration of } \\
\text { therapy }\end{array}$ & Goal of the study \\
\hline $\begin{array}{l}\text { Teale, et al. } \\
1998[18]\end{array}$ & 4 & $\begin{array}{l}\text { One patient was treated with dexamethasone } \\
4 \mathrm{mg} \text { three times a day. } \\
\text { Three patients were treated with prednisolone } \\
30 \mathrm{mg} \text { once daily. }\end{array}$ & 6 weeks -7 months & $\begin{array}{l}\text { To compare the effectiveness of hGH and } \\
\text { glucocorticoid therapy in NICTH by analyzing } \\
\text { the molecular distribution of different forms } \\
\text { of IGF-II and IGFBP-3. }\end{array}$ \\
\hline $\begin{array}{l}\text { Teale, et al. } \\
2004 \text { [20] }\end{array}$ & 6 & $\begin{array}{l}\text { Five patients were treated with prednisolone. } \\
\text { Different regimens included: } 20 \text { mg once daily; } \\
30 \mathrm{mg} \text { once daily; } 5 \mathrm{mg} \text { three times a day) } \\
\text { One patient was treated with dexamethasone } \\
4 \mathrm{mg} \text { once daily. }\end{array}$ & 6-13 months & $\begin{array}{l}\text { To compare the outcome of different } \\
\text { treatment options in NICTH }\end{array}$ \\
\hline $\begin{array}{l}\text { Bourcigaux, et } \\
\text { al. } 2005 \text { [9] }\end{array}$ & 1 & $\begin{array}{l}\text { Three different phases of study: phase } 1 \text { with } \\
\text { prednisone only, phase } 2 \text { with hGH only, phase } \\
3 \text { with both. } \\
\text { The lowest effective dose when steroids were } \\
\text { used alone was prednisone } 30 \text { mg. }\end{array}$ & $\begin{array}{l}\text { Days (experimental } \\
\text { study) }\end{array}$ & $\begin{array}{l}\text { To assess if combination therapy with low } \\
\text { dose steroid and hGH is effective in inoperable } \\
\text { patients with NICTH. }\end{array}$ \\
\hline $\begin{array}{l}\text { Perros, et al. } \\
1996[19]\end{array}$ & 1 & $\begin{array}{l}\text { Prednisone } 30 \mathrm{mg} \text { once daily given with a } \\
\text { combination of hGH and bendrofluazide; steroids } \\
\text { were lowered later to } 15 \mathrm{mg} \text { once daily } \\
\text { (only in combination), }\end{array}$ & 9 months & Case Report \\
\hline
\end{tabular}

${ }^{\mathrm{a} O n l y}$ the dose which achieved and maintained euglycemia is included

in conjunction with other therapies in cases of inoperable NICTH (Table 1). In aggregate, the initial dose of glucocorticoid was at least $30 \mathrm{mg}$ or its steroid equivalent dose, with attempts made to taper therapy based on the maintenance of euglycemia [19-21]. The minimum effective daily dose in cases employing only steroids was $20 \mathrm{mg}$ once daily or $5 \mathrm{mg}$ three times a day, with further dose reductions resulting in relapse of hypoglycemia $[18,20]$. The ideal duration of therapy remains unclear from the literature, with most studies having variable follow-up.

Our patient continued to have severe hypoglycemia as an inpatient. This was acutely treated with continuous infusions of both glucagon and dextrose. Once the diagnosis of recurrent NICTH was established, she was successfully transitioned to prednisone $40 \mathrm{mg}$ once daily, and euglycemia was achieved. Since surgical resection was not a viable option given the extent of her disease, imatinib was restarted after discussion with oncology with the aim of decreasing tumor burden. Over the next few months, she was successfully weaned off all steroids and repeat imaging demonstrated some shrinkage of the tumor with TKI therapy.

\section{Conclusion}

In summary, NICTH is a rare paraneoplastic phenomenon that has been described in association with a variety of neoplasms. The pathophysiology of NICTH arises from excessive tumor production of both IGF-II and its precursor "big" IGF-II, resulting in an altered IGF-I to IGF-II ratio and insulin-independent stimulation of the insulin receptor. While cases of GIST associated NICTH have been reported, to our knowledge, our patient remains distinctive in having an extremely rare extragastrointestinal GIST tumor with an even more rare presentation of non- islet cell tumor hypoglycemia. While definitive treatment involves tumor resection and/or adjuvant treatment with TKIs, corticosteroids have been shown to successfully alleviate hypoglycemia. The overall consensus from a limited number of published reports suggests initiating steroids at a dose of prednisone $30 \mathrm{mg}$ or higher and then tapering over weeks to months to the smallest dosage required to maintain euglycemia [18].

\section{Abbreviations}

CD117: Tyrosine kinase receptors c-kit; CD34: Hematopoetic progenitor cell antigen CD34; CT: Computed tomography; DOG1: Discovered on GIST-1; EGIST: Extragastrointestinal stromal tumor; GIST: Gastrointestinal stromal tumor; hGH: Human recombinant growth hormone; HHF-35: Monoclonal muscle specific actin antibody; HMB-45: Human melanoma black; IGFBP: IGF binding proteins; IGF-I: Insulin like growth factor I; IGF-II: Insulin like growth factor II; Melan-A: Melan-A/MART-1; NICTH: Non-islet cell tumor hypoglycemia; PDGFR-a: Platelet-derived growth factor-a; S-100: S-100 protein; TKl: Tyrosine kinase inhibitor

\section{Acknowledgements}

The authors acknowledge the support of the Islet and Physiology Core of the Indiana Diabetes Research Center (P30-DK-097512), the editorial assistance of Ms. Marilyn Wales, and the assistance of the Pathology and Radiology Departments at the Sidney and Lois Eskenazi Hospital in Indianapolis, Indiana.

\section{Funding}

Work in the laboratory of C.E-M is supported by NIH grants UC4 DK104166 and DK093954, VA Merit Award 101 BX001733, and JDFR grant SRA-2014-41 The contents of this article are solely the responsibility of the authors and do not necessarily represent the official views of the National Institutes of Health, the U.S. Department of Veterans Affairs or the United States Government, or the JDRF.

\section{Availability of data and materials}

Not applicable.

\section{Authors' contributions}

ZS and CE-M analyzed and interpreted patient data. ST performed the histological examination of tumor sections. All authors contributed to the writing the manuscript; all authors have read and approved the final manuscript. 


\section{Authors' information}

Not applicable.

\section{Competing interests}

The authors declare that they have no competing interests.

\section{Consent for publication}

Written permission to publish this case report was obtained from the patient.

\section{Ethics approval and consent to participate}

Reports describing the case of a single patient are exempt from review by the Indiana University School of Medicine Institutional Review Board.

\section{Author details}

${ }^{1}$ Departments of Medicine, Indiana University School of Medicine, Indianapolis, USA. ${ }^{2}$ Celllular and Integrative Physiology, Indiana University School of Medicine, Indianapolis, USA. ${ }^{3}$ Biochemistry and Molecular Biology, Indiana University School of Medicine, Indianapolis, USA. ${ }^{4}$ Herman B Wells Center for Pediatric Research, Indiana University School of Medicine, 635 Barnhill Drive MS 2031A, Indianapolis, IN 46202, USA. ${ }^{5}$ Roudebush VA Medical Center, Indianapolis, IN 46202, USA.

\section{Received: 11 August 2016 Accepted: 23 November 2016} Published online: 01 December 2016

\section{References}

1. Iglesias P, Diez JJ. Management of endocrine disease: a clinical update on tumor-induced hypoglycemia. Eur J Endocrinol. 2014;170(4):R147-57.

2. de Groot JW, Rikhof B, van Doorn J, Bilo HJ, Alleman MA, Honkoop AH, et al. Non-islet cell tumour-induced hypoglycaemia: a review of the literature including two new cases. Endocr Relat Cancer. 2007;14(4):979-93.

3. Walter HN, John AW. Hepatogenic hypoglycemia associated with primary liver cell carcinoma. Arch Intern Med (Chic). 1929:44(5):700.

4. Kumar AS, Padmini R, Veena G, Murugesan N. Extragastrointestinal stromal tumour of the abdominal wall - a case report. J Clin Diagn Res. 2013:7(12):2970-2.

5. Rikhof B, van Doorn J, Suurmeijer AJ, Rautenberg MW, Groenen PJ, Verdijk $M A$, et al. Insulin-like growth factors and insulin-like growth factor-binding proteins in relation to disease status and incidence of hypoglycaemia in patients with a gastrointestinal stromal tumour. Ann Oncol. 2009;20(9):1582-8.

6. Alkhatib L, Albtoush O, Bataineh N, Gharaibeh K, Matalka I, Tokuda Y. Extragastrointestinal stromal tumor (EGIST) in the abdominal wall: case report and literature review. Int J Surg Case Rep. 2011;2(8):253-5.

7. Goukassian ID, Kussman SR, Toribio Y, Rosen JE. Secondary recurrent multiple EGIST of the mesentary: a case report and review of the literature. Int J Surg Case Rep. 2012:3(9):463-6.

8. Dimofte MG, Porumb V, Ferariu D, Bar NC, Lunca S. EGIST of the greater omentum - case study and review of literature. Rom J Morphol Embryol. 2016;57(1):253-8.

9. Li ZY, Huan XQ, Liang XJ, Li ZS, Tan AZ. Clinicopathological and immunohistochemical study of extra-gastrointestinal stromal tumors arising from the omentum and mesentery. Zhonghua Bing Li Xue Za Zhi. 2005;34(1):11-4

10. Marks V, Teale JD. Tumours producing hypoglycaemia. Diabetes Metab Rev. 1991;7(2):79-91.

11. Zapf J. Role of insulin-like growth factor (IGF) II and IGF binding proteins in extrapancreatic tumour hypoglycaemia. J Intern Med. 1993;234(6):543-52.

12. Davda R, Seddon BM. Mechanisms and management of non-islet cell tumour hypoglycaemia in gastrointestinal stromal tumour: case report and a review of published studies. Clin Oncol. 2007;19(4):265-8.

13. Dynkevich Y, Rother KI, Whitford I, Qureshi S, Galiveeti S, Szulc AL, et al. Tumors, IGF-2, and hypoglycemia: insights from the clinic, the laboratory, and the historical archive. Endocr Rev. 2013;34(6):798-826.

14. Li H, Li J, Li X, Kang Y, Wei Q. An unexpected but interesting response to a novel therapy for malignant extragastrointestinal stromal tumor of the mesoileum: a case report and review of the literature. World J Surg Oncol. 2013;11(1):174.

15. Swalchick W, Shamekh R, Bui MM. Is DOG1 immunoreactivity specific to gastrointestinal stromal tumor? Cancer Control. 2015;22(4):498-504.
16. Escobar GA, Robinson WA, Nydam TL, Heiple DC, Weiss GJ, Buckley L, et al Severe paraneoplastic hypoglycemia in a patient with a gastrointestinal stromal tumor with an exon 9 mutation: a case report. BMC Cancer. 2007;7:13.

17. Blanke CD, Demetri GD, von Mehren M, Heinrich MC, Eisenberg B, Fletcher $J A$, et al. Long-term results from a randomized phase II trial of standardversus higher-dose imatinib mesylate for patients with unresectable or metastatic gastrointestinal stromal tumors expressing KIT. J Clin Oncol. 2008; 26(4):620-5

18. Teale JD, Marks $\vee$. Glucocorticoid therapy suppresses abnormal secretion of big IGF-II by non-islet cell tumours inducing hypoglycaemia (NICTH). Clin Endocrinol (Oxf). 1998:49(4):491-8.

19. Perros P, Simpson J, Innes JA, Teale JD, McKnight JA. Non-islet cell tumourassociated hypoglycaemia: $111 \mathrm{ln}$-octreotide imaging and efficacy of octreotide, growth hormone and glucocorticosteroids. Clin Endocrinol (Oxf). 1996:44(6):727-31.

20. Teale JD, Wark $G$. The effectiveness of different treatment options for nonislet cell tumour hypoglycaemia. Clin Endocrinol (Oxf). 2004;60(4):457-60.

21. Bourcigaux N, Arnault-Ouary G, Christol R, Perin L, Charbonnel B, Le Bouc Y. Treatment of hypoglycemia using combined glucocorticoid and recombinant human growth hormone in a patient with a metastatic nonislet cell tumor hypoglycemia. Clin Ther. 2005;27(2):246-51.

\section{Submit your next manuscript to BioMed Central and we will help you at every step:}

- We accept pre-submission inquiries

- Our selector tool helps you to find the most relevant journal

- We provide round the clock customer support

- Convenient online submission

- Thorough peer review

- Inclusion in PubMed and all major indexing services

- Maximum visibility for your research

Submit your manuscript at www.biomedcentral.com/submit
Biomed Central 